\title{
Climate Change and the Transition Movement in Eastern Europe: The Case of Czech Permaculture*
}

\author{
MARTA KOLÁŘOVÁ** \\ Institute of Sociology, Czech Academy of Sciences, Prague
}

\begin{abstract}
This paper focuses on a grassroots community movement addressing climate change: the transnational Transition (Towns) movement. While this movement has mainly spread to Anglophone countries, it is almost entirely absent from Eastern Europe and the Czech Republic in particular. The aim of this paper is to explain why the Transition movement-a grassroots community initiative- - has not been successfully adopted in the post-socialist Czech Republic, and why the issue of climate change has not become an important frame for the local permaculture movement which introduced the idea of Transition to the country. The paper presents an analysis of ideological frames and framing processes of the local movement. Reasons identified for the movement's absence from the Czech Republic include the fact that it was largely overshadowed by the broader post-socialist transformation in Eastern Europe, that there was little public awareness of climate change and no real culture of community organising in the post-socialist period, and that a strong climate scepticism was promoted by Czech political elites. Other reasons relate to the ideological frames of the local permaculture movement, which is centred more on prognostic and mobilising frames, combined with a positive agenda and an emphasis on practical activities, and revolves around individualised strategies and frames in which permaculture and a nature religion (Anastasian spirituality) are linked to the concept of a 'family homestead'. The research draws on in-depth interviews with permaculture practitioners, media analysis, the study of documents, and participant observation.
\end{abstract}

Keywords: climate change, social movements, Transition, community, permaculture

Sociologický časopis/Czech Sociological Review, 2020, Vol. 56, No. 3: 363-386

https://doi.org/10.13060/csr.2020.022

* This work was supported by the Czech Academy of Sciences, research programme Strategy AV 21 'Global Conflicts and Local Interactions'.

** Direct all correspondence to: Marta Kolářová, Institute of Sociology, Czech Academy of Sciences, Jilská 1, 11000 Prague, e-mail: marta.kolarova@soc.cas.cz.

(C) Sociologický ústav AV ČR, v. v. i., Praha 2020 


\section{Introduction}

Scholars and politicians have been discussing climate change as a serious environmental and social problem since the late 1980s. The academic consensus is that global climate change is a fact given the evidence of the increasing temperature of the atmosphere and oceans, the widespread melting of ice, and rising sea levels. Global warming is mostly caused by greenhouse gases being released in increasing volumes into the atmosphere as a result of the burning of fossil fuels. According to climate scientists, there is clear evidence of the human impact on the climate. Some of the consequences of global climate change include an extreme rise in temperatures and drought accompanied by flooding, which in some regions has caused malnutrition, starvation, death, migration, and poverty [IPCC 2018]. According to the Intergovernmental Panel on Climate Change (IPCC), it is necessary to limit warming to $1.5^{\circ} \mathrm{C}$ and reduce greenhouse gas emissions. Carbon dioxide emissions have nevertheless continued to increase year on year [IPCC 2018].

Although IPCC scholars, state politicians, corporations, and transnational organisations are the main players in negotiating climate change, various social movements have also become involved in this issue and since 2006 have come to form a new transnational movement focused on climate change [Dietz and Garrells 2014]. The climate movement has never been a homogeneous one, with a single collective identity to unite behind and a shared ideology or strategy [Caniglia, Brulle and Szasz 2015: 243]. There have always been multiple streams within the movement: first, there is the moderate branch of the movement, which sees the solution to global warming as lying within the existing social order; and second, there is the radical wing, whose approach to climate change is part of a systemic critique of capitalism and neoliberalism [Dietz and Garrells 2014; Cassegard et al. 2017]. There is also a wing made up of non-protest movements that focus on practical changes that emerge from the bottom up, such as grassroots community initiatives and lifestyle movements, the most visible example being the Transition (Towns) movement.

Climate change and the related activism have become a topical issue in the Czech media, especially since the extremely hot summer of 2018, the publication of the IPCC report, and the climate protest initiated by Swedish teen activist Greta Thunberg. However, there is a lack of research on climate activism in Czech scholarship. When this paper was begun in autumn 2018, there were not many movements yet dealing with climate change; but by the time the text was being revised in spring 2019, numerous initiatives, groups, and protest organisations had emerged. These processes, however, have not yet been addressed in academic research.

Work has been done on the radical environmental movement in general [Novák 2017], on the climate-sceptic countermovement [Vidomus 2018], on various aspects of environmental movements, mostly from the perspective of social- 
movement organisations (such as Greenpeace, the Green Party, Nesehnutí, etc.), and on protest events and tactics [Binka 2010; Císař 2011; Fagan 2004; Maslowski 2009]. Novák [2017] is currently working on research concerning the climate justice movement led by the Czech group Limity jsme my (which in English calls itself 'Limits Are Us'), which organises climate camps and protests against coalmining companies. But there has been no work on non-protest climate movements. This paper focuses on the Transition movement in the Czech Republic.

A look at the Transition Network map ${ }^{1}$ showing Transition initiatives and hubs in countries around the world reveals that there are many in Western Europe, but in the East the map is almost empty and there are only a few scattered initiatives. The majority of initiatives were active in anglophone countries at the beginning of the movement [Bailey, Hopkins and Wilson 2010], and nowadays four Western European countries (Italy, France, Great Britain, and Germany) are home to about forty-eight percent of all the initiatives within the Transition network [Feola and Him 2016].

Why have there been so few Eastern European Transition initiatives? And why has no community movement focused on climate change emerged in the Czech Republic?

This paper describes the Transition movement internationally and its spread into the Czech Republic through the permaculture movement. It outlines theoretical approaches to the study of non-protest social movements-i.e. grassroots community initiatives and lifestyle movements-and then turns to the view of climate change and community-organising in post-socialist countries and the Czech Republic in particular. The core of the paper involves an analysis of the ideological frames and framing processes of the local permaculture movement and an explanation of which frames are successful in mobilising people.

This paper seeks to explain: (1) why the Transition movement, which is based on grassroots community initiatives, has not been successful in the Czech Republic, and (2) why the climate change issue has not become an important frame for the local permaculture movement.

\section{Climate change and community activism: the Transition (Towns) movement}

Originating in Great Britain in 2006, the Transition movement focuses on supporting local responses to the risks related to climate change and peak oil and promotes ideas such as resilient communities, sustainability, relocalisation, and self-reliance. The movement's founder, permaculture teacher Rob Hopkins [2008], argues in The Transition Handbook that society is heavily reliant on oil and global chains of food production and this leaves communities in a highly vulner-

\footnotetext{
${ }^{1}$ https://transitionnetwork.org/transition-near-me/.
} 
able position if there were to occur any sudden shocks, fuel scarcities, or market instabilities and in the face of climate change effects. For this reason, he proposes that people build resilient communities by learning new skills and engaging in local cooperation and become increasingly reliant on local resources. Hopkins considers local communities the most significant agents of change [Hopkins 2008: 69]. The movement's actors promote energy descent planning and food localism, and they use activities centred on local food (for example, farmers' markets, permaculture projects, and community-supported agriculture) as strategies to reconnect people with nature and as an access point for attracting more participants. Transition initiatives use consensus decision-making and participatory democratic processes [Quilley 2015; Barr and Wright 2012]. Rooted in permaculture, a movement with an optimistic focus on action aimed at sustainability and personal responsibility that prioritises practice over theory [Ferguson and Lovell 2013; Lockyer and Veteto 2013], the Transition project has spread quickly across Europe and North America and is organised as a transnational movement by the Transition Network in forty-three countries through more than eleven hundred local Transition initiatives [Feola and Him 2016].

The idea of Transition spread to the Czech Republic through the permaculture movement, which has been active locally since the 1990s and has links to the West through personal ties and contacts. The Permakultura CS association organised a conference on the subject of Transition Towns in November 2014, which I attended. It was a two-day event with talks on the psychology of transition, Transition initiatives in Slovakia, discussions on permaculture's relation to the Transition movement, a presentation of community-supported agriculture (CSA), and panel discussions with members of some Czech eco-communities. In the event advertisement the 'Transition Movement' (an unknown concept locally) was defined as the transformation of society towards sustainability, self-reliance, and community activities. After the event, a booklet containing the papers presented by the conference participants was published and is still available for reading. ${ }^{2}$

Denisa Tomášková, a principal proponent of the Transition movement in the Czech Republic, and a permaculture teacher with a background in international education and experience in permaculture, presented her experience with founding a local Transition initiative in Boskovice in 2008, a small town in the South Moravian region. She later told me:

I followed the model; I bought the Transition handbook and tried to do it. We had several meetings, repeatedly. We had discussions and also activities. We planted trees and plants. People gathered at the community centre, and we organised activities with children. But the initiative ceased to exist after I moved for family reasons to another town.

${ }^{2}$ Transition: Změna k lepšimu. Sborník př́spěvků ze setkání na Toulcově dvoře 2014. Prague: Permakultura CS. 
No other initiative has originated in Czech society. Even though there has not been a public debate on communities transitioning towards sustainability and the issue of climate change in the Czech Republic, the theoretical work of Rob Hopkins is not unknown in Czech academia. Fraňková [2015], who studied the theory of localisation and local economy, quotes Hopkins' Transition Handbook as one of six significant books by authors who address localisation. Fraňková gives five examples of some localisation initiatives in the Czech Republic, mostly in the Brno region: LETS (local exchange trading system), CSA, social enterprises, car sharing, and a self-reliant community initiative. She does not, however, link these practical examples to any theoretical concepts, including that of the Transition movement.

In Czechia, we cannot speak of the Transition movement per se-I will try to explain what the local interpretation of term transition is-so I will instead study the permaculture movement that brought the idea of Transition to the Czech Republic and its relation to climate change.

\section{Theories on social movements, community initiatives, and lifestyle movements}

Several theoretical approaches to studying social movements in general have been developed: (a) the American paradigm of political opportunities and resources, (b) the European tradition of new social movements, and (c) theories of social movements in relation to globalisation and global social movements that proliferated at the end of the millennium (e.g. della Porta and Tarrow [2005], Guidry, Kennedy and Zald [2000], McDonald [2006]). The latter approach reflected a new wave of movements that primarily manifested themselves as enormous protest events organised around the summits of global actors such as the IMF or the WTO. However, as Mario Diani argues, less attention has been paid to the influence of global issues on civic organising at the local level [Diani 2005]. According to him, '[s]ocial movements have always developed in a creative tension between the local and the national (now also increasingly the transnational) sphere.' [Diani and Rambaldo 2007: 766]

The theoretical approach to the study of global protest events leaves out at least two things: First, it omits the localist strategies of global movements. Ayres and Bosia [2011] point out that protest summitry and large-scale mobilisations have overshadowed localism as an alter-globalisation strategy and that several global movements focus on local everyday activities and micro-resistance against neoliberal globalisation, as exemplified by the global food sovereignty movement Vía Campesina. Starr [2010], who has published on the alter-globalisation movement, recently also addressed 'local food' initiatives and studied them as a social movement with polycentric networks of various organisations. Despite acting locally, these grassroots initiatives associate with transnational networks of movements, including groups in both the Global North and the Global South. 
Second, all of the main social movement paradigms focus on public protest and social movement organisations, but they overlook movements that are less formal, focused on community initiatives or lifestyle activism, not engaged in public protests, and interested in positive change and practical activities. Community initiatives and lifestyle movements try to deal in practical ways with various aspects of the mitigation and adaptation to climate change.

A new wave of community-based sustainable initiatives has arisen that are promoting change towards sustainability.

These projects often have global environmental concerns at their heart, and express both an urgency for action (especially on climate change) and a belief that the local or small-scale offers the potential for this action to have a more substantial impact ... Many of the participants in these initiatives are disappointed by government's lack of action on climate change. [Middlemiss 2018: 173]

They promote bottom-up participation instead. There are numerous recent examples of grassroots community initiatives addressing the reduction of ecological and carbon footprints collectively: Transition towns, community gardens, community energy projects, CSA, local organic food systems, low-carbon eco-housing, community composting programmes, local currencies, and permaculture projects, etc. [Seyfang 2011].

Community participation is understood as a significant way to achieve lowcarbon practices and the carbon reduction transition [Middlemiss and Parrish 2010]. The communities involved do not have to be place-based; there are also communities centred on interests or practices - for example, the CSA, an instrument of the food sovereignty movement, which is a global network of peasants, farmers, and consumers. According to Sage [2014], growing food and organising events around food can induce civic engagement and help enhance social capital by sharing seeds, recipes, techniques, and experiences.

Other forms of non-protest movements that are focused on social change are represented by the lifestyle movements that were defined by Haenfler, Johnson and Jones [2012], who in their work seek to bridge the concepts of social movement and lifestyle. Lifestyle movements (LMs) are social entities that 'consciously and actively promote a lifestyle, or way of life, as their primary means to foster social change' [Haenfler, Johnson and Jones 2012: 2]. Examples of LMs are localvores, voluntary simplifiers, people who adopt the 'green life', etc., who want to change the world by creating a coherent lifestyle and identity. LMs 'are explicitly social change-oriented, often extra institutional, and persist over timebut are more individualistic rather than collective, personal rather than social, and tend to emphasise cultural targets rather than the state' [ibid.: 3]. Within lifestyle movements action occurs individually, in an everyday private setting, through cultural practices and goals. LMs have a diffuse structure of informal social networks and events, movement authorities, shared media, and lifestyle 
movement organisations, such as NGOs, civic organisations, and small businesses. In relation to climate change, LMs focus on mitigation and living low-carbon lifestyles-for example, by practising veganism and a car-free lifestyle, eating local food, growing one's own food organically, and engaging in do-it-yourself practices and self-reliance.

The idea that it is possible to have an impact on climate change and the environment through one's everyday activities is part of the concept of environmental citizenship [Dobson 2007]. It is based on the recognition that every action, including private decisions, has public environmental effects because in our lives we consume natural resources and produce waste. Dobson suggests calculating the environmental impact of different actors (individuals, companies, organisations) on the basis of their ecological footprint, which is defined as the environmental space an actor occupies. The concept of environmental citizenship calls for a combination of activities in both the public sphere (protests, acts, demands) and the private sphere (consumption of food, energy, clothing, etc.).

\section{Methods of data collection and analysis}

In my research into the permaculture movement I used a combination of methods: ethnography, the study of media, in-depth interviews, and media analysis. I conducted participant observation at sustainable demonstration sites, at public events organised by the movements, and at festivals, conferences, courses, open-garden days, and various meetings, and I carried out informal interviews throughout the course of my fieldwork. I studied print and media materials produced by the movement, such as websites, magazines, interviews, video-recorded talks, and books written by the movement's leaders, and I conducted twelve in-depth interviews with 'the movement's intellectuals' (permaculture teachers, organisers, and active practitioners), who were selected on the basis of ethnography and the study of movement literature and websites.

I conducted a qualitative media analysis to examine how permaculture and related movements are represented in alternative media (Pravý domácí časopis / The Real Homemade Journal) and used ethnographic content analysis to collect and analyse the qualitative data [Altheide 1996]. I created a protocol of analysed units using the programme MaxQDA.

In order to examine the movement's ideological frameworks, values, and mobilisation strategies, I drew on the concept of social movement frames developed by Snow and Benford [1988; Benford and Snow 2000]. Framing is an active, dynamic phenomenon that involves the agency of organisations and movement activists and contention over the construction of reality. The framing process gives rise to 'collective action frames' that simplify and condense aspects of the world in order to mobilise supporters. 'Collective action frames are action-oriented sets of beliefs and meanings that inspire and legitimate the activities and campaigns 
of a social movement organization.' [Benford and Snow 2000: 614] Frames help make events meaningful and are used to organise experience in action. Movement leaders are important actors in producing meaning for supporters. Snow and Benford [1988] developed a social movement model consisting of three main ideological frames: (1) diagnosis of a problematic event or aspect of society; (2) prognosis - a suggested solution to the problem and a clarification of what is to be done, including goals, strategies, and tactics; and (3) mobilisation-motivating participants to support the action.

\section{The absence of the Transition movement and a climate change frame in Eastern Europe and the Czech Republic}

There are several reasons why the idea of a grassroots community movement that would tackle climate change and peak oil-Transition-has not spread to the Czech Republic. One is a reason more generally applicable to Eastern Europe, and the others are local and limited to the Czech Republic: the different notion of transition in Eastern Europe, the Czech climate scepticism expressed by political elites, and the absence of community organising in the country

\section{Eastern Europe and the Transition movement}

With respect to Eastern Europe, an explanation as to why the permaculture concept of transitioning to a low-carbon society has not been taken up outside Western Europe is provided by Fox [2013], who studied rural peasants in Romania after accession to the European Union. There are two very different notions of 'transition' in the East and the West. In post-socialist discourse, transition meant the transformation of society as a whole out of the state-socialist past into a modern, civilised, Western capitalist future. On the other hand, the British permaculture movement had a different vision and was seeking a transition to a resilient and sustainable society, before which lie the challenges of climate change and peak oil. This vision is very different from the socialist one and difficult for Eastern Europeans to identify with. ${ }^{3}$

\footnotetext{
3 A similar situation happened, for instance, in South Africa in the 1990s, where transition meant a transition to democracy, not a transition towards sustainability [Swilling and Annecke 2012]. 'Whereas the European discussion is largely about low-carbon transition as an alternative to preserving the status quo, in many other parts of the world that are exploited for their resources the alternative to transition may well be collapse.' [ibid.: xvii] Swilling and Annecke stress the importance of 'just transitions' and addressing inequalities both between states and within them.
} 
Hana Klenovská [2011], in her master's thesis on the Transition movement in the United Kingdom, mentions three Transition initiatives in Eastern Europe: in Latvia, Poland, and Hungary. When she asked activists in those three countries what were the major challenges to founding local initiatives, they said that the problem was that there was very little public awareness of climate change and peak oil and a lack of literature on these issues in 2010. The language barrier may have been the reason why the Transition initiatives spread first and mostly to anglophone countries. People in Eastern Europe did not know about these problems, and they did not feel the need for change. Another difficulty, Klenovská argues, was that between 2008 and 2011 society's main focus was on the economic crisis and unemployment. Eastern Europeans, furthermore, saw themselves as having a lower standard of living and level of consumption, and not as causal agents of overconsumption. The themes of energy and climate change were understood as a luxury. Other aspects of post-socialist countries Klenovská mentioned as significant include the still weak state of civil society, the absence of a 'culture of community' in towns or neighbourhoods, and the growth of individualism. After decades of state socialism, a resistance arose to communitarian ideals such as togetherness and the common good. On the other hand, there are numerous positive resources conducive to a possible transition in Eastern Europe: there seems to be greater resilience in the population, resulting from a strong tradition of self-help, do-it-yourself, and self-reliance and the practical skills possessed by older generations, and facilitated by a well-developed system of public transport and local food production [Klenovská 2011].

This argument is supported by the research of Petr Jehlička, who has studied the self-provisioning of food in Eastern Europe. He has shown that household self-provisioning is more widespread in post-socialist countries than in the West because it was a common practice under the state-socialist regime. Jehlička, Kostelecký, and Smith [2013] show that food self-provisioning is still practised by a significant proportion of the Czech population across all social groups, and, rather than being motivated by economic needs, it serves as a hobby and a way of accessing fresh food. Vávra, Daněk, and Jehlička [2018] argue that regular gardeners contribute to reducing greenhouse gas emissions, even though their motivation for food self-provisioning is not an environmental one.

There are, however, people in the Czech Republic who have a post-materialist orientation in life and who are interested in environmental issues, quality of life, and alternatives to consumer lifestyles. These people have been studied by Hana Librová [1994, 2003; Librová et al. 2016], who frames their activities through the concepts of voluntary simplicity, ecological luxury, and the generational transmission of simplicity. Librová et al. [2016: 264] and her students Kala, Galčanová, and Pelikán [2017] argue that Czechs who practise the environmentally-friendly lifestyle of voluntary simplicity do so intuitively, and they found that the participants in their research ('the colourful') could not be identified with any movement. The argument that these people do not identify with any movement 
is based on a research sample from 1992, before transnational movements had spread to Czechoslovakia. That movement emerged in the Czech Republic later in the 1990s, but Librová based her subsequent research on the original sample.

\section{Czech climate scepticism}

The issue of climate change is not only an issue in the realm of (natural) science, as approaches to it have also been strongly shaped by culture, political contestation, and contrasting worldviews [Hoffman 2017]. The Czech Republic has been specific in that strong climate scepticism has been observed among its political elites and right-wing think-tanks and has been expressed foremost by former president Václav Klaus [Vidomus 2018]. These individuals and groups have in a public and organised manner consistently questioned the importance of climate change and its anthropogenic origin. Climate scepticism was strongest in the years 2007-2008 ${ }^{4}$ and it was led by think-tanks that brought in important sceptics from abroad to speak on the issue in the Czech Republic. The sceptics presented their arguments as expertise, which created the impression that climate science is the subject of controversy and differing opinions, and this then led to the postponement of any political activity on climate change. 'The expertization (not necessarily professionalization) is thus an efficient strategy of deproblematization of the phenomenon that environmental movements and climatologists find significant.' [Vidomus 2018: 384] Public opinion on the issue of global warming was influenced by the Czech president and related sceptics questioning the existence of climate change. A quantitative sociological study (European Social Survey Round 8) showed that most Czech people are not interested in the issue of climate change (53\%), $44 \%$ are not afraid of climate change, and $60 \%$ do not feel personally responsible for climate change [Plecitá 2017].

More detailed research by Krajhanzl, Chabada, and Svobodová [2018] found that $29 \%$ of the Czech citizenry deny the existence of climate change, while $52 \%$ think that climate change is happening and 19\% do not know. Even people who are aware of the risks connected to climate change are not concerned about its impact on their life and their environs. Czech people place the responsibility for dealing with climate change primarily on the state, industrial corporations, and global players such as the European Union, while assigning the least responsibility to individuals. Czechs are very sceptical of what impact their individual behaviour could have on mitigating climate change. Only a minority of Czech citizens claimed to have changed their consumption behaviour, and $64 \%$ of people do not take climate change into consideration when making consumer choices.

${ }^{4}$ Climate movements and the Transition movement also emerged and started to grow in Western Europe also emerged around this same time. 
Meanwhile, an even smaller share of the population engages in any political activities focused on climate issues: $13 \%$ of Czechs reported doing voluntary activities, $10 \%$ said they had given financial support to climate protection, and $9 \%$ claimed to have signed a petition [Krajhanzl, Chabada and Svobodová 2018].

\section{Political participation and community organising in the Czech Republic}

Another reason climate change is not an issue in the Czech Republic is the weak level of political participation and lack of a communitarian approach in the country. Linek et al. [2017], in a study of citizenship and political participation in the Czech Republic after 1989, found, in agreement with international research, that post-socialist citizens have less interest in politics than their Western counterparts and do not participate in political activities, whether that means political parties or civil society organisations. Czechs have a much lower rate of non-electoral civic participation than what is observed among citizens in Western democracies, even though the Czech rate of participation is the highest among the postsocialist countries [Linek et al. 2017: 202].

Environmental movements, Císař [2013] notes, have for the most part been especially transactional in their activism, which in Eastern Europe and the CR in particular predominantly takes the form of small advocacy organisations with no membership base that are funded by external agencies and European Union programmes. Grassroots movements are less significant in this region, and those that have become visible are radical or oriented around protest and direct action.

Community organising is not a practice that has been typically observed in the Czechia. Frič and Vávra [2012], who studied Czech communities in the context of voluntary activities, argue that the Czech Republic is still quite far from being 'a society of communities'. While a strong tradition of Czech cooperative movements emerged in the 19th century, these civic activities were severely restricted under the communist regime and associations of citizens were limited to mass organisations centrally controlled by the regime. Most of the civic NGOs that arose after 1989 are sports, recreational, and hobby organisations. Although there are about a hundred thousand such associations, Czechs are not very good neighbours. They are inclined to paternalism, and they like to rely on the state to take care of them. The local political culture is characterised by a social and not group-based collectivism. The many years of socialist atomisation of civic society led to a culture of separation, where the individual is perceived as existing outside the bonds of any community [Frič and Vávra 2012], and the word 'community' itself is almost entirely absent from everyday communication. The Czech public do not understand the terminology of communitarianism, a philosophical ideology that sounds too much like communism for it to be able to enjoy any popularity among Czechs. There is no ambition to build a society of communities the way there is in the United States or Great Britain [Frič and Vávra 2012]. 


\section{The Transition and permaculture movements in the Czech Republic}

The idea of Transition was brought to the Czech Republic by the permaculture movement. Permaculture is based on a design system developed by Mollison and Holmgren [1978] in 1970s Australia to sustain the diversity and resilience of ecosystems while integrating people and their needs into the local landscape. Permaculture puts emphasis on practice over theory [Ferguson and Lovell 2013] and can be understood as a methodological tool kit for individuals, communities, and ecovillages [Veteto and Lockyer 2008].

Permaculture spread to the Czech (and Slovak) Republic in the mid-1990s, when some British teachers came and taught the first permaculture courses. The first students of those courses founded the Czechoslovak association Permakultura CS. Since then, the association has organised permaculture courses, including the internationally recognised 72-hour Permaculture Design Course (PDC), and they have created a network of permaculture demonstration sites with thirty-five projects. I visited or met people from places such as Pozemská zahrada, U Jiř́ka, Těšíkovská bydlina, Zahrada na kopci, Farm Jagava, and others). The Permakultura CS association has published books (Encyclopaedia of Self-reliance for the $21^{\text {st }}$ Century, edited by Eva Hauserová, the association's chairperson) and booklets in a series titled The Key to Self-reliance, and in the past it also had its own magazine-The Keyhole. The association organises annual two-day conferences on topics related to permaculture (permaculture design, permaculture farms, etc.) and runs a website with information about permaculture, events, publications, etc. Permakultura CS also serves as an arbiter of the movement's values, as it certifies demonstration permaculture sites and each year awards a diploma to selected projects.

The association's work is also based on networking. It promotes many other issues, movements, and organisations related to permaculture and supports ecocommunities and community-supported agriculture schemes. ${ }^{5}$ Permakultura CS also promotes community-garden activities, such as Kompot and Kuchyňka, two community gardens located in and near Prague. Some of these garden projects are directly organised by members of Permakultura CS, such as Garden Bohumila in the Prague district of Kolovraty or the Garden Without Fences in Žamberk.

\footnotetext{
${ }^{5}$ It is difficult to call the eco-communities in the Czech Republic a movement as they are scattered and form rather small groups of friends or families who want to live communally in rural areas (for example, Mrkev, Těšíkovská bydlina, Ekozámeček Stroupeček, Sklenářka). Some projects have already ceased to exist, while others strive to continue. By my estimation, in the autumn of 2018 there were at most ten eco-communities in the country with approximately two hundred inhabitants in total.

CSA activities are supported by the food sovereignty movement, represented by NGOs such as the Association of Local Food Initiatives, CSA associations, or Cooland, who focus on the right to healthy food produced in a sustainable way. The first impulse to start Czech CSA initiatives came in 2009 from France. Since then, the concept has continued to spread, and in 2018 there were about thirty communities with roughly six hundred members.
} 
Today, Permakultura CS has about seventy members and about 1,500 followers. It has an affiliated association, the Academy of Permaculture, and both organisations are dominated by women-the core organisers are mostly middleaged or senior women, some living with children, some without. As well as these two female-led organisations, there are also some teachers who operate independently. The most influential practitioner of permaculture in the Czech Republic is Jaroslav Svoboda, famous for his book Ecogardens, which many exponents of this practice quoted as their 'bible'. He is a charismatic figure who has managed to attract many people to permaculture, and he has organised his own courses since 2005, even though he is not internationally certified through the PDC to teach permaculture. He has approximately three thousand followers. He was the only permaculture leader who refused to give me an interview, but I was able to attend some of his courses (Permaculture in the City in 2014 and Planting a Tree Spiral in 2015). I also analysed his extensive website, Ekozahrady.cz, interviews that have been conducted with him, and articles he has published in the media (on the national radio services and in, for example, the magazine Regena).

Svoboda owns about nineteen hectares of fields in the northern part of the Czech Republic, where he has planted thousands of trees, grows a vegetable garden, and lives in a 'natural' home with his partner. Together they work on his vision of creating a paradise on Earth. In his teaching and writings, he has linked permaculture to spirituality and, in particular, to Anastasian spirituality. Anastasians are a Russian environmental and spiritual movement that wants to create a new alternative society by building 'family homesteads' - local, self-sufficient, one-hectare lots [Pranskevičiute 2015]. Anastasians are the fastest-growing ecovillage movement in contemporary Russia and the movement has now spread to the West. It was inspired by the teachings of Anastasia, a fictional character in the novels of Vladimir Megre. Jaroslav Svoboda, who created a Czech version of these 'family homesteads', has managed to attract many people to attend his courses, where they learn how to build family homesteads from scratch on a plain field.

\section{The ideological frames and values of the permaculture movement}

According to Snow and Benford [1988; Benford and Snow 2000], analysing the main ideological frames of a movements starts with defining the problem the movement is concerned with and what the movement aims to change. While for the transnational Transition movement it is climate change and peak oil, this frame is largely absent from the Czech permaculture movement. Even though many of the movement's activities are practically oriented towards mitigating or adapting to climate change, global warming as such is not mentioned.

For the Czech permaculture movement, the issue of climate change is relevant in reports brought back from international 'convergences', but not in the Czech movement. The only exception is an article by a permaculture lector Marek Kvapil, who studied philosophy and sociology and who writes about the conse- 
quences of climate change for the local climate, agriculture, and the adaptability of various crops. ${ }^{6}$ After a very hot and dry summer in 2018, another permaculture teacher, Denisa Tomášková, reacted by offering a practical course on water management and protecting gardens against drought.

Asked directly about the global context of permaculture activities, the Czech permaculture teachers I interviewed replied that while the global situation is important, they feel it counterproductive to scare people with negative facts. They then quickly switched to talking about local situations, either in a village or a private garden, and how to design the particular site in a sustainable way. One female permaculture teacher told me:

People expect from us recipes and instructions for cultivation, combinations of plants, and they attend the course with the understanding that they will learn there. In PDC, we find that people want to compost and plant beds and they do not want to listen to the global situation of the world's environment and resources.

The permaculture teachers also said that Czech people see the Transition and the climate change issue as 'something foreign and prescribed from above, and that they do not want to adopt some recipe from Great Britain'. (E. H., a permaculture leader, female, senior) The idea of permaculture (and the related issues and frames), however, also did not originate in the Czech Republic. Another permaculture teacher talked about the local Czech situation: 'Compared to England, people here under socialism were accustomed to a DIY approach, making, mending, growing food in their mini gardens. So, we are not that nervous about climate change. In Britain, there are people who aren't even able to plant a seed. Here people have gardens, have chickens, have contact with that.' (D. T., a permaculture teacher, female, middle age)

In permaculture circles climate change is understood more in terms of its negativity and how that is communicated to us by the media:

We hear about the problems of the contemporary world all the time: biodiversity loss, erosion, climate change, unemployment, migrants, health problems-you can probably name a lot of other pieces of scattered information that the media throws at us. What can a person do with such a flood of negativity? We can give up and stick our heads in the sand, or we can do something meaningful. For me permaculture is a source of this kind of meaningful activity. (I. M., a permaculture teacher, female, middle age $)^{7}$

${ }^{6}$ Kvapil, M. 2014. 'Permakulturní zahradničení v době klimatické změny.' (Permaculture gardening in the age of climate change) Retrieved 10 April 2016 (http://www.potravinovezahrady.cz/permakulturni-zahradniceni-v-dobe-klimaticke-zmeny/).

7 Mertová, I. 2016. 'Zemřel Bill Mollison, zakladatel permakultury' (Bill Mollison, the founder of permaculture, has died) Retrieved 2 June 2018 (https://www.permakulturacs. cz/article/91/zemrel-bill-mollison-zakladatel-permakultury). 
This quote demonstrates both the movement's disinterest in politics, with climate change being perceived as a part of high politics rather than an everyday problem, and the practical and DIY orientation of the permaculture movement, with very little focus on critiquing larger issues and those responsible for them. In other words, permaculture's diagnostic frames are weak. There are aspects of the critique and diagnostic frames that can be found in prognostic framings, making these two types of frames sometimes difficult to separate. For example, when the movement's leaders criticise consumerism, the unsustainability of industrial agriculture, low-quality food full of chemicals, and subsequent lifestyle diseases, they contrast these with their own visions of a clean environment, healthy and quality food, biodiversity, improved wellbeing, and so on.

The themes and goals of the permaculture movement are healthy soil/ land, healthy food, sustainable food production (either via sustainable agriculture or subsistent homesteading), healthy and sustainable lifestyles, and community building (in the organisational and women-led branch of the permaculture movement).

In the analysis, I uncovered three main values or principles and divided them into separate blocks: (1) sustainability and a turn towards nature; (2) self-reliance and autonomy; and (3) a change of consciousness (or spirituality). This first value is a strong relationship with nature, encompassing a desire to be natural and an effort to improve the environment. It is related to a desire to care for the Earth, but also to more self-interested values-being healthy, living in harmony with nature. This value is expressed in the act of growing one's own food (or sourcing it from local organic farmers), moving out of the city, living in close contact with nature in naturally built houses made of renewable materials, and so forth. It can also be framed as espousing sustainability and living lightly on the Earth.

Permaculture has sustainability in its name: permanent (agri)culture. Originally, it dealt with sustainable, permanent agriculture and homesteading, but later applied its principles to other spheres of human life. Permaculture has three ethical principles: Earth care, people care, and fair share. The principles of permaculture design include, for instance, using renewable energy, systemic thinking, collaborating with nature, seeing a problem as a solution, producing no waste, and using and valuing diversity.

A permaculture garden is inspired by nature. This means that, when creating it, we try to imitate the natural ecosystem, its structure, function, and the relations between its elements. (M. K., a permaculture teacher, male, in his 30s)

The second value is represented by the freedom and autonomy of individuals, freedom from the influence of state institutions and corporations, and self-reliance. It is about independence, responsibility for the self, and a belief in creativity and in the agency of the individual to change society by changing one's lifestyle. This value is manifested as self-provisioning, or avoiding corporations when buying food, and in subsistence homesteading, seed-saving, do-it-yourself 
activities, creating an 'island system' - a house with an independent energy system-and so on.

The term self-reliance is very popular in Czech permaculture and related initiatives. It figures in the names to related associations (Academy of Self-reliance), publications (Encyclopaedia of Self-reliance), and courses and educational activities (Course of Self-reliance), and it has been the thematic focus of some festivals (Allfestival in Litoměřice 2016). Self-reliance may be motivated by worries about the future and alienation:

People are scared of both some catastrophe and worsening conditions, and they really want to learn things that would enable them to live in harsher conditions. And they are fed up with the sense of alienation involved in using things when they don't know how they are made. (E. H., a permaculture leader, female, senior)

In the permaculture of post-socialist Czech society, self-reliance is mostly framed in relation to the individual; it is not understood as the self-reliance of whole communities.

A change of consciousness represents a reflective approach to life and an interest in the roots of social issues. The particular form of spirituality is not an imperative part of permaculture. Czech permaculturalists are inclined towards various forms of spirituality (from atheist to Catholic or Buddhist), but the Anastasian natural spirituality has predominated. The teachings of Svoboda, the independent permaculturalist, are imbued with spirituality and transcendence:

Working with a seedbed transforms into a sacred ceremony, sowing the seed into an initiation of new creation, and the fertilising of the soil expresses an elemental desire for life. The harvest is a joyous celebration of abundance, composting waste is a transformation of death into a new and stronger life. The gardener, who feels his divine position in the midst of the rotating Universe, knows that all substance is just an energy that he is creating with his own mind. ${ }^{8}$

\section{Framing processes: diffusion, resonance, and the transformation of frames}

The frames that spread to the Czech Republic from abroad after 1989 included: the idea of permaculture, which originated in Australia; the concept of family homesteads from Russia; and eco-communities, the models for the Czech versions of this idea being Findhorn in Scotland, Sieben Linden in Germany, and

\footnotetext{
8 Svoboda, J. 2015. 'Úvod do vědomého pěstování zeleniny v živé zahradě, uprostřed vesmíru.' (An introduction to the conscious cultivation of vegetables in a living garden, in the middle of the universe') Retrieved 1 May 2016 (http:/ / ekozahrady.com/zelenina_uvod. htm).
} 
Zaježová in Slovakia. The frames are foreign but have been diffused to the local level, where the form they take may be quite different from the original ones. The success of the movement's frames is dependent on their resonance within the local culture. Resonance refers to how effective they are and the size of their mobilisation potential [Benford and Snow 2000].

Resonance is related to credibility, which depends on frame consistency, meaning how well the values, claims, and activities of the movement correspond to each other. If there is a discrepancy, the movement is not as credible, the frames resonate less, and mobilisation is more difficult [Benford and Snow 2000]. For instance, one of the main values is sustainability, but by migrating to rural areas people become dependent on cars, which are not a sustainable means of transportation. This dependency also contradicts the value of self-reliance because of the dependency on oil. So, individuals (or families) who prefer a sustainable lifestyle without a car and are against car pollution will have difficulty accepting the idea of moving to a rural area.

The credibility of a frame depends also on the correspondence between the framing and events in the outer world. When there is more evidence, the framing is more credible. The movements try to show that the change they promote is possible. For permaculture, correspondence exists at the diagnostic level: nature is being destroyed, we eat unhealthy food from the supermarket-these are things that everyone has encountered. Prognostic and motivational framing is also related to things that exist in the real world. The movements' leaders present examples of good practices and point out that change is possible and real. They give examples from their own life (how they built a natural home, how they grow vegetables and plant trees, etc.), and they collect information and promote demonstration sites-houses and gardens that function according to permaculture principles, and examples of successful projects and eco-communities abroad.

The credibility of a frame is also influenced by the perceived credibility of the leaders: who in order to enjoy credibility must have built a reputation for themselves, prove themselves as experts, and must be knowledgeable. The leaders of the permaculture movement tend to use their official education less in their self-narratives, with some of them even distancing themselves from it. They instead present their alternative education in the sphere of permaculture as more important. Their credibility is, however, mostly based on their authenticity and practical experience-take, for instance, this description of a permaculture leader:

Since the mid-1990s, she has been living permaculture. She sets up gardens and community networks. She picks wild and cultured plants. She makes ayurvedic balms and preserves old and rare varieties of seeds. As an employee and volunteer, she has worked in many NGOs, and as a volunteer she has lived on many farms around Europe. She is a founding mother of numerous specific projects; for instance, Mrkev, an organic vegan farm and association, and the Garden of the Good, a public demonstration garden. She loves Ayurveda and teaches it and permaculture under 
the label Permayoga. She has almost no free weekends because she is giving talks, lectures, teaching, and passing on what she knows, likes, and is meaningful to her. (magazine Pravý domácí časopis /The Real Homemade Journal, 6/2015: 4)

The movement's credibility receives a further boost when celebrities are invited to take part in book launches or talks (for instance, the famous Czech actors Jaroslav Dušek and Simona Babčáková are known for their support for alternative projects).

Besides credibility, the salience of the frames is another important factor that influences a frame's resonance. Salience is related to meanings of how ideas are important in the lives of those the mobilisation is aimed at. Salience depends on the commensurability of experience, on how compatible the frames are with one's personal experience, or whether they are too abstract and remote from life. The experience of local people with self-provisioning, self-help building, and other DIY activities was strong under socialism. However, homesteading and farming in rural areas was rare because of the collectivisation of land implemented by the communist regime. Furthermore, the transnational movements introduced the new idea of sustainability and have reframed DIY activities as organic, sustainable, and ecological.

Salience depends on narrative fidelity, which refers to how well frames resonate with great cultural narratives and ideologies. In the Czech Republic, the ideas of freedom and individualism introduced by the leader of the 'family homestead' concept were the ones that resonated most. Also, the definition of a family homestead represents a transformation of a local frame. Svoboda defines the homestead not as a traditional village house or a farm suited for animal breeding. Rather, in his view it should be a 'great paradisal natural oasis', a space created on a former farmland, a fenced one-hectare area in which you plant trees, and, later, maybe a natural house (or a trailer). On a radio programme, Svoboda stated, 'I personally do not see the homesteading of past centuries as a model, because it involved too much labour. That seems pointless to me. The hard work was focused on growing food for feeding animals and handing over most of the crop to the gentry. ${ }^{\prime 9}$

Svoboda believes that everyone should buy at least a one-hectare plot of land, and he claims it should be the right of every Czech citizen to own a hectare of land. The premise of his idea is that it is possible to be completely self-sufficient with one hectare of land, and he does not count, for instance, the increased environmental footprint of people having to get around in cars if they live in a rural area. The current ecological footprint of the Czech population is 5.36 global hectares per person (while the available bio capacity is only 2.47) [Vačkář 2019]

\footnotetext{
${ }^{9}$ Interview with permaculturalist J. Svoboda on Czech Radio 2, 17 May 2016. (https:// dvojka.rozhlas.cz/zakladem-permakultury-je-aby-se-vegetace-starala-sama-osebe-7482188).
} 
because of imported goods and industry. So, his vision of environmental citizenship is based much more on rights than responsibilities.

Svoboda has also transformed the local frame of voluntary simplicity ${ }^{10}$ and replaced it with the rhetoric of individualism and self-interest.

The main aim is to ensure the prosperity of humans so that they do not have to impose a false modesty on themselves and deny their own needs ... The best thing about permaculture design is that it does not force people to do something because it is good for the natural environment. That would not really work. If you look around, you understand that the pursuit of self-interest is primordially encoded within human nature. ... Protecting and improving the environment is a bonus, a pleasant and inseparable side effect. ${ }^{11}$

This individualistic frame has proved to be a successful mobilising strategy.

Svoboda was successful in two framing processes: (1) frame bridging-he bridged the frames of the quasi-scientific permaculture approach with those of Russian natural spirituality and other influences (channelling and human design); and (2) frame amplification-he amplified the frames of permaculture through the use of positive vocabulary and concepts such as joy, natural abundance, prosperity, love, creativity, and harmony. For him, in conformity with the views of the Anastasians, the family homestead is primarily a 'space of love'. He promotes the view that we are all the creators of our own paradise on Earth, and we should follow our vision of a life in harmony with nature.

However, the concept of a family homestead with a one-hectare area is an issue of frame disputes, both within the permaculture movement and from the perspective of other movements. For instance, the leader of the food sovereignty movement sees it as a very selfish idea: 'It is escapism and separation from society, and I take a negative view of this. It is a way backwards. It might be good for an individual, but not for a society, and I want change for the whole of society.'

\section{Conclusion}

There are several reasons why the concept of a grassroots community movement tackling climate change and peak oil-Transition-has not taken hold in the Czech Republic. While there are some reasons that apply more generally to Eastern Europe as a whole, others are specifically Czech, and others are inherent to Czech permaculture.

\footnotetext{
${ }_{10}$ Voluntary simplicity was the main research frame used by Librová [1994, 2003] and her students to study environmentally-friendly lifestyles.

${ }^{11}$ Svoboda, J. 2009. Kompletní návod k vytvoření ekozahrady a rodového statku. (A complete guide to creating an eco-garden and family homestead), 10-11.
} 
The overall situation in Eastern Europe, with its grand transformation from socialism to capitalism and democracy, has overshadowed the new concept of a Transition to a sustainable future, which was developed in the Western countries. In the transformation years Eastern Europeans also had little awareness of climate change issues. The absence of a culture of community-organising and the low level of non-electoral political participation in this region had a further impact on the local level, and in the case of the Czech Republic and in the environmental sphere these activities were then further stunted by the strong climate scepticism on the part of its political elites, foremost among them the former president Václav Klaus.

There are also other reasons that are more inherent to the permaculture movement. The frame analysis here showed that the movement is oriented towards practical change, and that they incentivise action rather than complicated theoretical frames, such as climate change. A critique of the system or particular institutions is missing to some degree; permaculture proposes solutions and practical guidelines for everyday life. The framing is usually positive with efforts to motivate people in a good way and not frighten them with negative messages. Prognostic and motivational framing dominate over diagnostical, and it has resonated in the Czech Republic because of a local culture of DIY activities and selfprovisioning.

The permaculture movement has used frames of sustainability, self-reliance, and spirituality as the main values and ideas guiding their activities. The frame most successful in having a mobilisation effect-in terms of adherent numbershas been the 'family homestead' frame related to individualism and natural spirituality, using positive and transcendental vocabulary and attracting people with ideas of freedom, abundance, joy, and love. This frame rejects voluntary modesty and rather promotes the pursuit of self-interests. It is aimed at individuals and has resulted in individual action in private settings, not in collective efforts and building communities. The other branch of permaculture, women-led and organisational in form, supports community projects (eco-communities, community gardens, and community supported agriculture), but it would be an exaggeration to speak of a larger community movement or community activism in the Czech Republic. Eco-communities are of small importance and are not very numerous; the number of community gardens and CSA is growing, but these are communities oriented around interests in leisure or consumption, and they are not for the most part political or civic initiatives aimed at contributing to public debates on climate change and sustainability. Therefore, in general, I would prefer to call Czech permaculture a lifestyle movement focused on individual practices and lifestyles instead of a community movement. Czech permaculturalists fulfil their environmental citizenship in the private sphere, and much less so in the public sphere by engaging in organising activities with others.

The conclusions of this paper may contribute to the ongoing debate on how to communicate about climate change with the public and how to mobilise people into action. The way to attract members of the Czech population seems to rest 
on the use of positive vocabulary and not frightening them with catastrophic scenarios. Moreover, a stress on practical activities resonates among Czechs; therefore, a focus on adaptation strategies (for example, how to retain water, fertilise the soil, or support local farmers) might be successful. It is important to resonate with local values and experiences. Voluntary simplicity, even though it is crucial to reducing the carbon footprint, is not a term with any mobilising force; thus, I believe that mobilisation on climate change mitigation will be more difficult, as people do not want to limit their consumption. It seems that the value of modesty needs to be communicated by means of other terms, be it minimalism, energy descent, health, self-reliance, or the future of our children.

MARTA KoláŘová is a senior researcher at the Institute of Sociology, Czech Academy of Sciences. Her research interests include social movements, subcultures and lifestyles in relation to globalization and sustainability.

\section{References}

Altheide, D. L. 1996. Qualitative Media Analysis. London: SAGE Publications, https://doi.org/10.4135/9781412985536.

Ayres, J. and M. J. Bosia. 2011. 'Beyond Global Summitry: Food Sovereignty as Localised Resistance to Globalization.' Globalizations 8 (1): 47-63, https://doi.org/10.1080/14747731.2011.544203.

Bailey, I., R. Hopkins and G. Wilson. 2010. 'Some Things Old, Some Things New: The Spatial Representations and Politics of Change of the Peak Oil Relocalisation Movement.' Geoforum 41 (4): 595-605, https://doi.org/10.1016/j.geoforum.2009.08.007.

Barr, S. and P. Devine-Wright. 2012. 'Resilient Communities: Sustainabilities in Transition.' Local Environment 17 (5): 525-532, https://doi.org/10.1080/13549839.2012.676637.

Benford, R. D. and D. A. Snow. 2000. 'Framing Processes and Social Movements.' Annual Review of Sociology 26: 611-639, https://doi.org/10.1146/annurev.soc.26.1.611.

Binka, B. 2010. Zelený extremismus. (Green Extremism) Brno: MUNI.

Caniglia, B. S., R. J. Brulle and A. Szasz. 2015. 'Civil Society, Social Movements, and Climate Change.' Pp. 235-268 in Climate Change and Society: Sociological Perspectives, edited by R. E. Dunlap and R. J. Brulle. New York: Oxford University Press, https://doi.org/10.1093/acprof:oso/9780199356102.003.0008.

Cassegard, C., L. Soneryd, H. Thorn and A. Wettegren. 2017. Climate Action in a Globalizing World. Comparative Perspectives on Environmental Movements in the Global North. London: Routledge, https://doi.org/10.4324/9781315618975.

Císař, O. 2011. 'Externally Sponsored Contention: The Channelling of Environmental Movement Organisations in the Czech Republic after the Fall of Communism.' Pp. 48-67 in Green Activism in Post-Socialist Europe and the Former Soviet Union, edited by A. Fagan and J. Carmin. New York: Routledge.

Císař, O. 2013. 'Post-communism and Social Movements.' Pp. 994-999 in Encyclopedia 
of Social and Political Movements, Vol. 3, edited by D. Snow, D. della Porta, B. Klandermans and D. McAdam. London: Blackwell.

Della Porta, D. and S. Tarrow. (eds) 2005. Transnational Protest and Global Activism. Lanham: Rowman \& Littlefield.

Diani, M. 2005. 'Cities in the World: Local Civil Society and Transnational Issues in Britain.' Pp. 45-67 in Transnational Protest and Global Activism, edited by D. della Porta and S. Tarrow. Lanham: Rowman \& Littlefield.

Diani, M. and E. Rambaldo. 2007. 'Still the Time of Environmental Movements? A Local Perspective.' Environmental Politics 16 (5): 765-784, https://doi.org/10.1080/09644010701634109.

Dietz, M. and H. Garrells. 2014. Routledge Handbook of Climate Change Movement. London: Routledge, https://doi.org/10.4324/9780203773536.

Dobson, A. 2007. 'Environmental Citizenship: Towards Sustainable Development.' Sustainable Development 15 (5): 276-285, https://doi.org/10.1002/sd.344.

Fagan, A. 2004. Environment and Democracy in the Czech Republic: The Environmental Movement in the Transition Process. Cheltenham: Edward Elgar Publishing, https://doi.org/10.4337/9781845420604.

Feola G. and M. R. Him. 2016. 'The Diffusion of the Transition Network in Four

European Countries.' Environment and Planning A 48 (11): 2112-2115, https://doi.org/10.1177/0308518X16630989.

Ferguson, R. S. and S. T. Lovell. 2013. 'Permaculture for Agroecology: Design, Movement, Practice, and Worldview.' Agronomy for Sustainable Development 34 (2/2014): 251-274, https://doi.org/10.1007/s13593-013-0181-6.

Fox, K. 2013. 'Putting Permaculture Ethics to Work: Commons Thinking, Progress, and Hope.' Pp. 164-179 in Environmental Anthropology Engaging Ecotopia: Bioregionalism, Permaculture, and Ecovillages, edited by J. Lockyer and J. R. Veteto. New York: Berghahn Books.

Frič, P. and M. Vávra. 2012. Tři tváře komunitního dobrovolnictví: neformální pomoc, organizovaná práce a virtuální aktivismus. (The three faces of communitarian voluntary activities: informal help, organized work and virtual activism) Prague: Agnes, Hestia.

Fraňková, E. 2015. Lokální ekonomiky v souvislostech aneb produkce a spotřeba z blizka. (The local economy in context or production and consumption close up) Brno: Masarykova univerzita.

Guidry, J. A., M. Kennedy and M. N. Zald 2000. Globalization and Social Movements. Michigan: University of Michigan, https://doi.org/10.3998/mpub.11707.

Haenfler, R., B. Johnson and E. Jones. 2012. 'Lifestyle Movements: Exploring the Intersection of Lifestyle and Social Movements.' Social Movement Studies 11 (1): 1-20, https://doi.org/10.1080/14742837.2012.640535.

Hoffman, A. J. 2017. Jak kultura utváří diskusi o klimatické změně. (How culture shapes the climate change debate) Brno: Masarykova univerzita.

Hopkins, R. 2008. The Transition Handbook: From Oil Dependency to Local Resilience. Cambridge: Green Books.

IPCC. 2018. Global Warming of $1.5^{\circ} \mathrm{C}$. An IPCC Special Report on the Impacts of Global Warming of $1.5^{\circ} \mathrm{C}$ above Pre-Industrial Levels and Related Global Greenhouse Gas Emission Pathways, in the Context of Strengthening the Global Response to the Threat of Climate Change, Sustainable Development, and Efforts to Eradicate Poverty. Intergovernmental Panel on Climate Change, Geneva. Retrieved 20 June 2019 (https://www.ipcc.ch/sr15/).

Jehlička, P., T. Kostelecký and J. Smith. 2013. 'Food Self-provisioning in Czechia: Beyond Coping Strategy of the Poor.' Social Indicators Research 111 (1): 219-234, https://doi.org/10.1007/s11205-012-0001-4. 
Kala, L., L. Galčanová and V. Pelikán. 2017. 'Narratives and Practices of Voluntary Simplicity in the Czech Post-Socialist Context.' Sociologický časopis/Czech Sociological Review 53 (6): 833-856, https://doi.org/10.13060/00380288.2017.53.6.377.

Klenovská, H. 2011. Transition Towns ve Velké Británii. (Transition towns in Great Britain) Brno: MUNI.

Krajhanzl, J., T. Chabada and R. Svobodová. 2018. Vztah české veřejnosti k přírodě a životnimu prostredí. (The Czech public's relationship to nature and the environment) Brno: MUNI.

Librová, H. 1994. Pestři a zelení: Kapitoly o dobrovolné skromnosti. (The colourful and the green: chapters on voluntary simplicity) Brno: Veronika, Hnutí Duha.

Librová, H. 2003. Vlažní a váhaví: kapitoly o ekologickém luxusu. (The half-hearted and the hesitant: chapters on ecological luxury) Brno: Doplněk.

Librová, H., V. Pelikán, L. Galčanová and L. Kala. 2016. Věrní a rozumní: kapitoly o ekologické zpozdilosti. (The faithful and the reasonable: chapters on ecological foolishness) Brno: MUNI, https://doi.org/10.5817/CZ.MUNI.M210-8412-2016.

Linek, L., O. Císař, I. Petrúšek and K. Vráblíková. 2017. Občanství a politická participace $v$ České republice. (Citizenship and political participation in the Czech Republic) Prague: Sociologické nakladatelství (SLON).

Lockyer, J. and J. R. Veteto. 2013. ‘Environmental Anthropology Engaging Ecotopia: An Introduction.' Pp. 1-31 in Environmental Anthropology Engaging Ecotopia: Bioregionalism, Permaculture, and Ecovillages, edited by J. Lockyer and J. R. Veteto. New York: Berghahn Books.

Maslowski, N. 2009. 'Social Protests and the World of the Environmentalists in the Czech Republic.' Pp. 40-55 in Social Movements and Public Action, Lessons from Environmental Issues, edited by P. Marty and S. Devaux. Prague: CEFRES.

McDonald, K. 2006: Global Movements: Action and Culture. Oxford: Blackwell.

Middlemiss, L. 2018. Sustainable Consumption: Key Issues. London: Routledge, https://doi.org/10.4324/9781315628035.

Middlemiss, L., and B. D. Parrish. 2010. 'Building Capacity for Low-carbon Communities: The Role of Grassroots Initiatives.' Energy Policy 38 (12): 7559-7566, https://doi.org/10.1016/j.enpol.2009.07.003.

Mollison, B. and D. Holmgren. 1978. Permaculture One. Sydney: Transworld Publishers.

Novák, A. 2017. Tmavozelený svět: Radikálně ekologické activity v ČR po roce 1989. (A dark-green world: radical environmental activities in the Czech Republic after 1989) Prague: Sociologický nakladatelství.

Plecitá, K. 2017. 'Češi a Češky se nezajímají o změnu klimatu a velké obavy ze změny klimatu nemají.' (Czechs are not interested in climate change and they are not worried by it) Press report. https://www.soc.cas.cz/aktualita/cesi-cesky-se-nezajimaji-ozmenu-klimatu-velke-obavy-ze-zmeny-klimatu-nemaji.

Pranskevičiute, R. 2015. 'Communal Utopias within Nature-Based Spiritualities in the Post-Soviet Region: The Visions of an Ideal World among Vissarionites and Anastasians.' Pp. 183-200 in The Borders of Subculture: Resistance and the Mainstream, edited by A. Dhoestet al. New York: Routledge, https://doi.org/10.4324/9781315722733-12.

Quilley, S. 2015. 'Ecocultures of Transition: New, Traditional and Alternative Ways of Living in the "Adjacent Possible".' Pp. 199-217 in Ecocultures: Blueprints for Sustainable Communities, edited by S. Böhm, Z. P. Bharucha and J. Pretty. London and New York: Routledge, https://doi.org/10.4324/9780203068472-12.

Sage, C. 2014. 'The Transition Movement and Food Sovereignty: From Local Resilience to Global Engagement in Food System Transformation.' Journal of Consumer Culture 14 (2): 254-275, https://doi.org/10.1177/1469540514526281. 
Seyfang, G. 2011. The New Economics of Sustainable Consumption: Seeds of Change. Basingstoke: Palgrave Macmillan.

Snow, D. A. and R. D. Benford. 1988. 'Ideology, Frame Resonance, and Participant Mobilization.' International Social Movement Research 1: 197-218.

Starr, A. 2010. 'Local Food: A Social Movement?' Cultural Studies-Critical Methodologies 10 (6): 479-490, https://doi.org/10.1177/1532708610372769.

Swilling, M. and E. Annecke. 2012. Just Transitions: Explorations of sustainability in an Unfair World. Claremont, South Africa: UCT Press.

Vačkár̆, D. 2019. Ekologická stopa České republiky. (The Czech Republic's environmental footprint) Enviwiki. Retrieved 27 June 2019 (https://www.enviwiki.cz/w /index. php?title=Ekologick\%C3\%A1_stopa_\%C4\%8Cesk\%C3\%A9_republiky\&oldid=22561).

Vávra, J., P. Daněk and P. Jehlička. 2018. 'What is the Contribution of Food Selfprovisioning for Environmental Sustainability? Case Study of Active Gardeners.' Journal of Cleaner Production 185: 1015-1023, https://doi.org/10.1016/j.jclepro.2018.02.261.

Vidomus, P. 2018. Oteplí se a bude líp: Česká klimaskepse v čase globálních rizik. (It will get warmer and things will be better: Czech climate scepticism in the time of global risks) Prague: Sociologické nakladatelství (SLON).

Veteto, J. R. and J. Lockyer. 2008. 'Environmental Anthropology Engaging Permaculture: Moving Theory and Practice Toward Sustainability.' Culture \& Agriculture 30 (1 \& 2): 47-58, https://doi.org/10.1111/j.1556-486X.2008.00007.x. 